\title{
Diolcogaster choi sp. nov. from Brazil, a new gregarious microgastrine parasitoid wasp (Hymenoptera: Braconidae) reared from Hypercompe cunigunda (Lepidoptera: Erebidae) in Brazil
}

\author{
Geraldo Salgado-Neto ${ }^{1^{*}}(\mathbb{C}$, Ísis Meri Medri², José L. Fernández-Triana³ \\ James Bryan Whitfield ${ }^{4}$
}

\author{
${ }^{1}$ Universidade Federal de Santa Maria, Departamento de Defesa Fitossanitária, Pós-graduação em Agronomia, Santa Maria, RS, Brasil. \\ ${ }^{2}$ Universidade de Brasília, Departamento de Ecologia, Doutorado em Ecologia, Brasília, D F, Brasil. \\ ${ }^{3}$ Canadian National Collection of Insects, Arachnids, and Nematodes, Ottawa, Ontario, Canada. \\ ${ }^{4}$ University of Illinois at Urbana-Champaign, Department of Entomology, Urbana, USA. \\ urn:Isid:zoobank.org:pub:28F860D2-5CDB-4D55-82BC-C41CFE1ADD0E
}

\section{A R T I C L E I N F O}

\section{Article history:}

Received 23 August 2019

Accepted 17 December 2019

Available online 00 Month 0000

Associate Editor: Bernardo Santos

\section{Keywords:}

Caterpillar

Natural Enemy

Parasitoid

Passiflora eduli

Passionflower

\begin{abstract}
A B S T R A C T
A new species of Diolcogaster(Hymenoptera: Braconidae) is described and illustrated. Additionally, its position within the recently published key to New World species of the xanthaspis species-group (to which the described Diolcogaster belongs) is provided. The gregarious larval parasitoid Diolcogaster choi sp. nov. was collected in Maringá, Paraná State, Brazil. This natural enemy was recovered from a caterpillar of Hypercompe cunigunda(Stoll, 1781) (Lepidoptera: Erebidae) that was feeding on plant of passionflower, Passiflora edulis Sims (Passifloraceae). The fauna of the xanthaspis group in the New World now includes five species, including the new species from Brazil described in this paper. Diolcogaster choi sp. nov. differs anatomically, and is morphologically diagnosed, from all other known member of the xanthaspis group of the genus Diolcogaster, to which it belongs. The species also differs in recorded host, and its DNA barcode appears to be distinctive among described Diolcogaster.
\end{abstract}

\section{Introduction}

The genus Diolcogaster belongs to the subfamily Microgastrinae (Hymenoptera: Braconidae) which comprises 2,700+ described species (Yu et al., 2016; Whitfield et al., 2018) and many thousands of additional undescribed ones (Rodriguez et al., 2013; Fernández-Triana and Boudreault, 2016; Fernández-Triana and van Atcherberg, 2017; Moghaddam and Mokhtari, 2017; Fernández-Triana, 2018). Microgastrinae is the single most important group of parasitoid wasps attacking caterpillars (Whitfield, 1997; Avila et al., 2013; Fernández-Triana et al., 2014; Pereira et al., 2015; Fiaboe et al., 2017), with many species used or being considered as biocontrol agents against lepidopteran pests in agriculture and forestry (Yeargan and Braman, 1986; Smith et al., 2013; Pinto et al., 2014). Diolcogaster is currently the seventh largest genus of Microgastrinae, with 101 species described worldwide

\footnotetext{
* Corresponding author.

E-mail: gsalgado@bol.com.br (G. Salgado-Neto)
}

(Zeng et al., 2011; Fernández-Triana, 2015; Fernández-Triana et al., 2016; Moghaddam et al., 2019) and hundreds awaiting description. Currently this genus has 18 species recorded from the New World, 11 from the Neotropical region, and five in Brazil (Gupta and Fernández-Triana, 2014, 2015; Yu et al., 2016; Salgado-Neto et al., 2018; Whitfield et al., 2018).

This paper describes a new Diolcogaster species from Brazil, perhaps with potential for the biological control of Hypercompe cunigunda(Stoll, 1781)(Lepidoptera: Erebidae), pest of the passionflower Passiflora edulis Sims (Passifloraceae; Spencer and Seigler, 1983) in the state of Paraná. This plant is economically significant due to its pharmacological and medicinal properties (Patel, 2009) and food commercial value chain.

The genus Hypercompe occurs from the USA through the Caribbean to Argentina and Bolivia, and contains 89 species (Vincent and Laguerre, 2014). Hypercompe cunigunda is found from French Guiana, Suriname, Peru, Brazil, Venezuela, Ecuador, Bolivia and Guatemala 
(Silva et al., 1968; Nava et al., 2008; BoldSystems, 2019) and was described using individuals collected of samples from Paraná, Brazil. Larvae of this species have been recorded feeding on the palm Syagrus romanzoffiana (Cham.) Glassman (Arecaceae) (Robinson et al., 2010) as well as Melothria pendula L. (Cucurbitaceae) (Gernaat et al., 2016), but there are few published studies on this species, and probably few if any other $H$. cunigunda host plants have been reported in the scientific literature. Larvae of Erebidae (Arctiidae in the old classification) including Hypercompe spp., generally are polyphagous and feed on a variety of species and individuals plants, even during the same day (Singer and Bernays, 2009). Some of these species, such as Hypercompe indecisa (Walker, 1855), have been reported as a pest of leaves and ears of corn; however in recent years this species has also been reported to cause damage in the early stages of the crop, feeding at the base of the soil and causing tipping of the plant. Besides corn, they also feed on leaves of more than twenty host plants, including various vegetables, potatoes, cabbage, lettuce and tomatoes. In addition, the fruit trees avocado, persimmon, strawberry and peach have been recorded as hosts. Although Hypercompe was reported as a corn pest in 1968 (Silva et al., 1968) little is known about its biology, ecology and biological control (Nava et al., 2008; Gernaat et al., 2016).

The new Diolcogaster parasitoid wasp species, described in this paper, should be considered for future studies about its possible potential for biological control of Hypercompe cunigunda caterpillars that cause crop damage on cultivated passion fruits.

\section{Materials and methods}

One last instar caterpillar of $H$. cunigunda was observed feeding on leaves of passion fruit, Passiflora edulis, on 28 December 2018, in the garden of one of the authors (Í. M. Medri), in Maringá, (Fig. 1), Paraná,

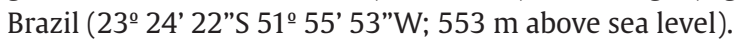

The caterpillar was collected with a fine-tipped brush, placed in a $500 \mathrm{~mL}$ plastic container lined with filter paper with the lid aerated, and with leaves provided ad libitum of the respective host plant as food and substrate for pupation (Tavares et al., 2012). On the next day, 39 cocoons were observed on the caterpillar's exterior after it had died. After 12 days, in 9 January 2019, 39 adult wasps emerged from the cocoons, 14 individuals were released and 25 wasps were sacrificed using ethyl ether and preserved by immersion in $70 \%$ ethanol. The caterpillar, $H$. cunigunda, and 5 open cocoons also were preserved by immersion in 70\% ethanol and were sent to Geraldo Salgado-Neto of "Coleção de Parasitóides do Laboratório de Biologia Evolutiva da Universidade Federal de Santa Maria - UFSM", with registration Hypercompe cunigunda Erebidae 2019 and Diolcogaster Ísis 2019, respectively.

A total of 25 wasps collected ( 22 females and 3 males) had the following destination: a) 2 females and 1 male were sent to Alvaro Doria dos Santos of "Museu de Zoologia da Universidade de São Paulo MZUSP"; b) 5 females and 1 male were sent to José L. Fernández-Triana of Canadian National Collection (CNC) of Insects, Arachnids, and Nematodes; c) 5 females and 1 male were sent to James Bryan Whitfield of Illinois Natural History Survey - INHS Insect Collection; d) 5 females were sent to Geraldo Salgado-Neto of "Coleção de Parasitóides do Laboratório de Biologia Evolutiva da Universidade Federal de Santa Maria - UFSM"; e) 4 females were sent to Ricardo Harakava of "Instituto Biológico" for analyses of the COI barcode; f) 1 female stayed with the collector Ísis Meri Medri for provide part of pictures for article illustration.

Photographs of the wasps were taken using DSLR camera with a $100 \mathrm{~mm}$ macro lens, in Brazil, and with digital camera photography attached to stereoscopic microscopes, at the University of Illinois. Morphological terms and measurements of structures are mostly those used by Fernández-Triana et al. (2014).
To check the molecular-specific characterization of the new species, the mitochondrial gene Cytochrome Oxidase I(COI) was analyzed. For the amplification of a fragment of approximately $460 \mathrm{bp}$ of this gene, we used the following primer pair: COI-F (5'-GATTTTTTGGKCAYCCMGAAG-3') and COI-R (5'CRAATACRGCTCCTATWGATAAWAC-3') (Gusmão et al., 2010). DNA extraction of one specimen was performed with the GenElute Mammalian Genomic DNA Miniprep Kit (Sigma-Aldrich ${ }^{\circledR}$ ) and followed the manufacturer's protocol. The product was amplified via PCR according to the following schedule: $94^{\circ} \mathrm{C}$ for 2 minutes, 40 cycles of $94^{\circ} \mathrm{C}$ for 30 seconds, $54^{\circ} \mathrm{C}$ for 30 seconds, $72^{\circ} \mathrm{C}$ for 40 seconds and $72^{\circ} \mathrm{C}$ for 4 minutes. Then the PCR product was purified using polyethylene glycol precipitation (PEG; Schmitz and Riesner, 2006). These samples were sequenced using the Big Dye 3.1 reagent (Life Technologies ${ }^{\circledR}$ ) and $3500 \mathrm{xL}$ automatic sequencer (Life Technologies ${ }^{\circledR}$ ).

\section{Molecular identification}

The molecular characterization of $D$. choi was carried out by sequencing the mtDNA COI gene of two specimens from Brazil. Consensus sequences from Brazil showed one SNP (single nucleotide polymorphism) located 280 bp into the alignment; it was identified as a pyrimidine substitution (T/C). The NCBI/Genbank deposit generated the accession number MK952186 for Brazil. The cladogram (Fig. 2) was reconstructed based on analyses of the COI region performed by the General Time Reversible nucleotide substitution model with Gamma distributed with invariant sites (GTR + I + gamma); parameters for partial exemption (95\%) were estimated as the best substitution model using MEGA 5.0 software (Tamura et al., 2011). The largest possible

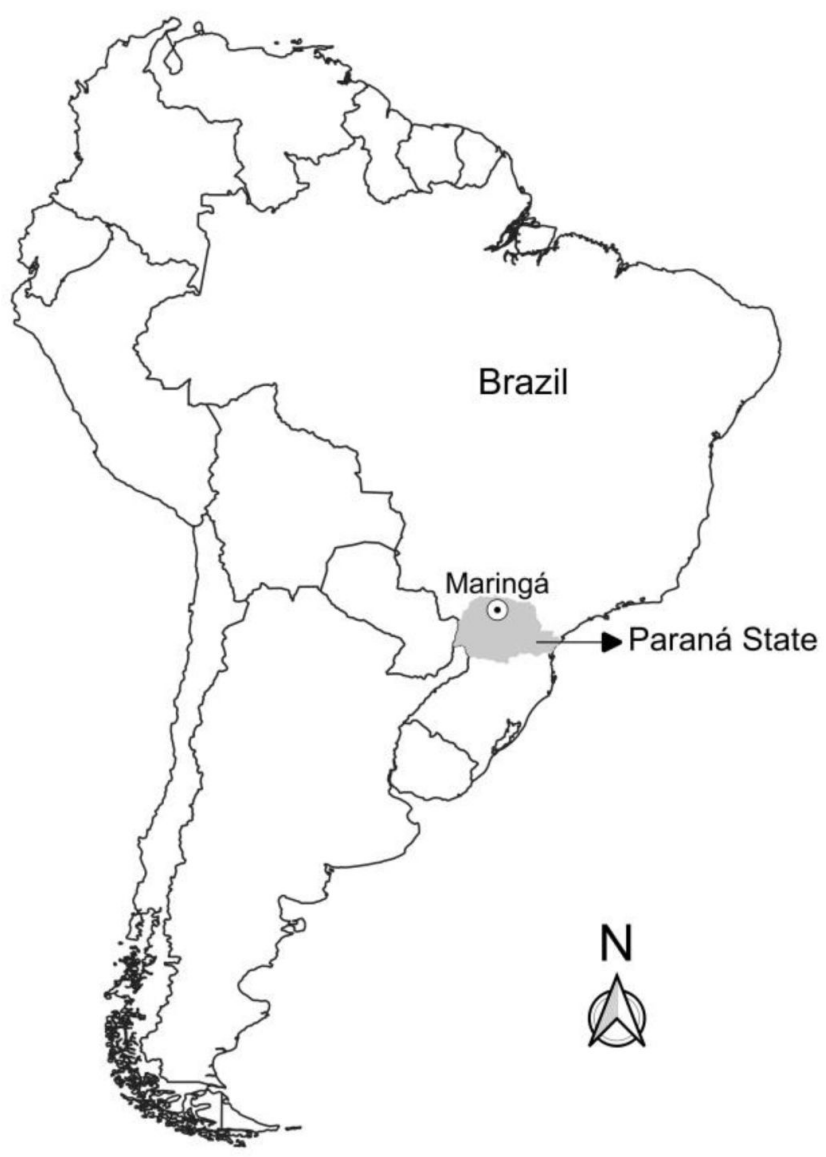

Figure 1 Geographical location of the Brazilian municipality of Maringá in the Paraná State. 
number of accessioned comparative sequences already deposited in NCBI was included to perform the phylogenetic analyses of barcodes, which was inferred with the maximum likelihood method as in Tamura and Nei (1993).

\section{Results and discussion}

Diolcogaster choisp. nov. belongs to the xanthaspis species-group, as characterized and keyed for the New World by Salgado-Neto et al. (2018).

Accounting for the new species from Brazil being described in this paper, the fauna of the xanthaspis group in the New World now includes five species (Table 1). The new species will key out in the key of Salgado-Neto et al. (2018) to D. flammeus Salgado-Neto and Fernandez Triana, 2018, but differs from that species in a number of features listed in the differential diagnosis.
Species description

Diolcogaster choi Whitfield \& Salgado-Neto sp. nov.

Holotype. 1 female deposited at the "Museu de Zoologia da Universidade de São Paulo" - MZUSP 62277, Maringá, Paraná State, Brazil, 232' 22”S 51ํ 55’ 53”W, 553 m above sea level, 09.i.2019, coll. Ísis Meri Medri, ex. larva Hypercompe cunigunda. Paratypes. 1 female and 1 male deposited at the "Museu de Zoologia da Universidade de São Paulo" - MZUSP 62278 and MZUSP 62279 respectively. 4 females and 1 male deposited at the Canadian National Collection (CNC) of Insects, Ottawa, Ontario - CNC 649484, CNC649485, CNC 649486, CNC 649487 and CNC 649488 respectively. 5 females and 1 male deposited at the Illinois Natural History Survey (INHS Insect Collection) - INHS 834744, INHS 834745, INHS 834746, INHS 834747, INHS 834748 and INHS 834749 respectively. 3 females deposited at the "Coleção de Parasitóides do Laboratório de Biologia Evolutiva

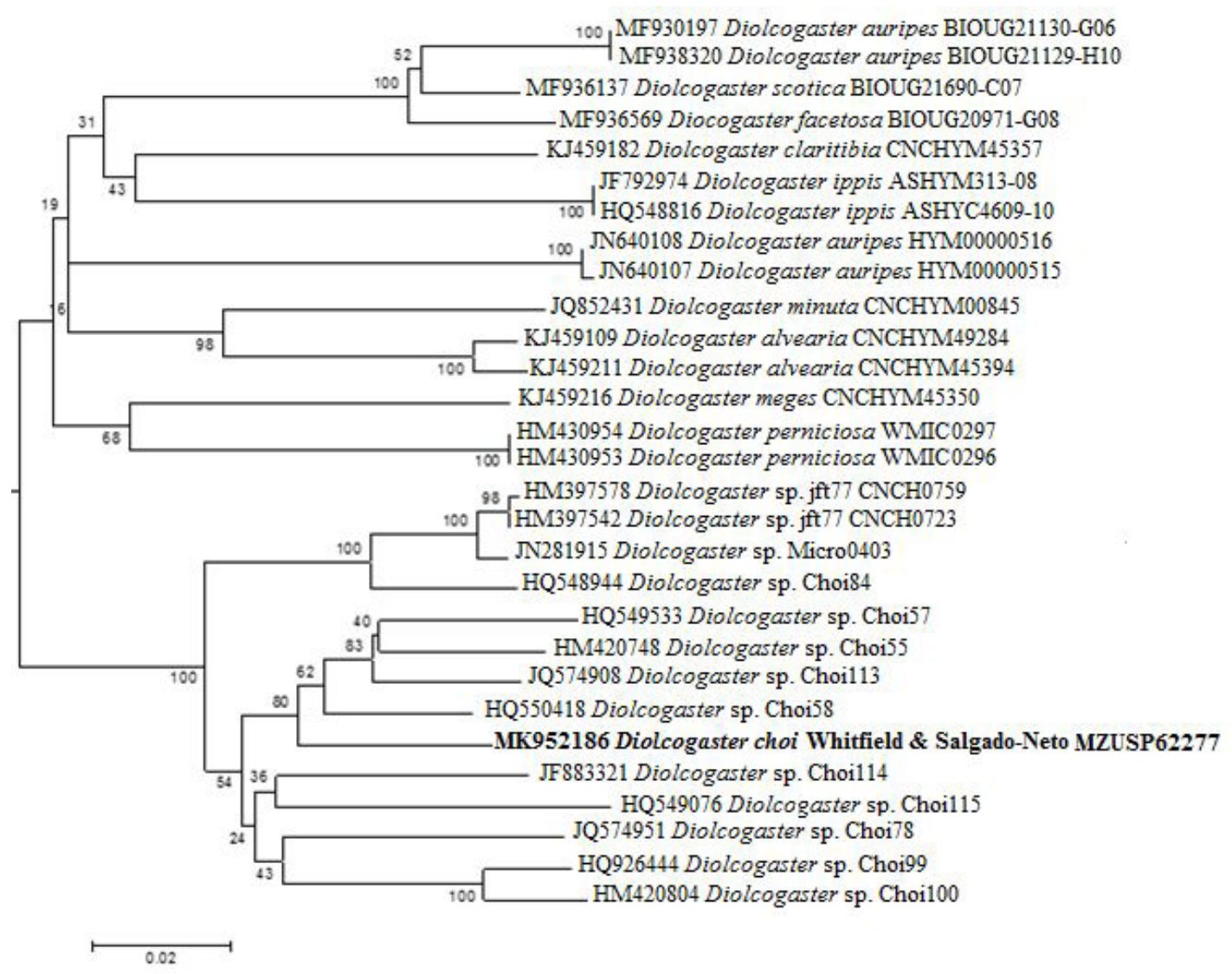

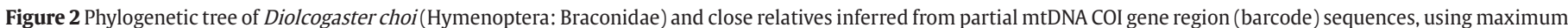
likelihood (ML) analysis. The numbers preceding the scientific names are the respective COI GenBank access codes.

Table 1.

Species of Diolcogaster (Hymenoptera: Braconidae) in the New World and respective hosts (Lepidoptera), geographical distribution, caterpillar hostplants and references.

\begin{tabular}{|c|c|c|c|c|}
\hline Diolcogaster spp. & Geographical Distribution & Host Caterpillar & Caterpillar Hostplants & Reference \\
\hline $\begin{array}{l}\text { D. choi Whitfield \& Salgado-Neto, } \\
2019\end{array}$ & Maringá, State of Paraná, Brazil & $\begin{array}{l}\text { Hypercompe cunigunda } \\
\text { (Stoll, 1781); Erebidae }\end{array}$ & Passiflora edulis Sims; Passiflorae & Present Study \\
\hline $\begin{array}{l}\text { D. flammeus Salgado-Neto \& } \\
\text { Fernández-Triana (2018) }\end{array}$ & Mexico to Brazil & $\begin{array}{l}\text { Agaraea minuta (Schaus, 1892); } \\
\text { Erebidae }\end{array}$ & $\begin{array}{l}\text { Costus spicatus (Jacq.) Sw. and } \\
\text { C. spiralis (Jacq.) Roscoe var. spiralis; } \\
\text { Costaceae }\end{array}$ & Salgado-Neto et al. (2018) \\
\hline D. iridescens (Cresson, 1865) & Cuba and Southern USA (Florida) & $\begin{array}{l}\text { Asciodes gordialis Guenée, 1854; } \\
\text { Crambidae }\end{array}$ & $\begin{array}{l}\text { Species, of Bougainvillea; } \\
\text { Nyctaginaceae }\end{array}$ & Patton (1958) \\
\hline D. bakeri (Muesebeck, 1922) & $\begin{array}{l}\text { Canada (Ontario, Quebec and } \\
\text { Saskatchewan), USA (Arkansas, } \\
\text { Florida, Georgia, Illinois, Iowa, } \\
\text { Kansas, Louisiana, and Texas) }\end{array}$ & $\begin{array}{l}\text { Ponometia candefacta } \\
\text { (Hübner, 1831) and P. erastrioides } \\
\text { (Guenée, 1852); Noctuidae }\end{array}$ & $\begin{array}{l}\text { Asteraceae including species of } \\
\text { Aster and Ambrosia }\end{array}$ & $\begin{array}{l}\text { Pogue (2010); } \\
\text { Stojanović et al. (2011) }\end{array}$ \\
\hline D. xanthaspis (Ashmead, 1900) & Saint Vincent and the Grenadines & Unknown & Unknown & Ashmead (1900) \\
\hline
\end{tabular}


da Universidade Federal de Santa Maria" - UFSM, with registration Diolcogaster Ísis 2019. Same data of locality, data, host and collector as holotype for all paratypes.

Description. Female (Fig. 3 and 4). Body color entirely yellow to orange yellow, except for dark brown to black on flagellomeres, parts of the scape, and most of the interocellar area, black ovipositor sheaths, darkened hind tibial apices and hind tarsi, and occasionally dorsum of extreme posterior metasomal segments partly brown. Fore wing with pterostigma and veins very dark brown to black. Head mostly with striate sculpture on face, frons, gena and vertex; occiput strongly concave and smooth. Mesosoma with anteromesoscutum and scutellar disc coarsely punctate, scutellar disc posteriorly with a slight keel; propodeum with
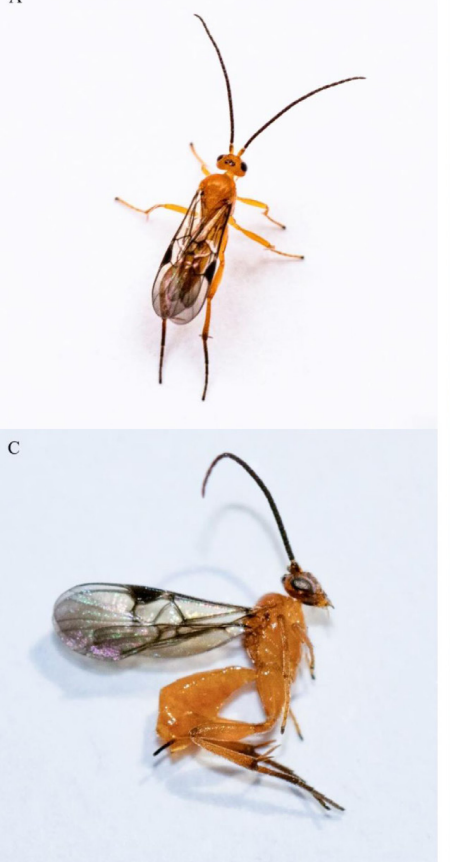

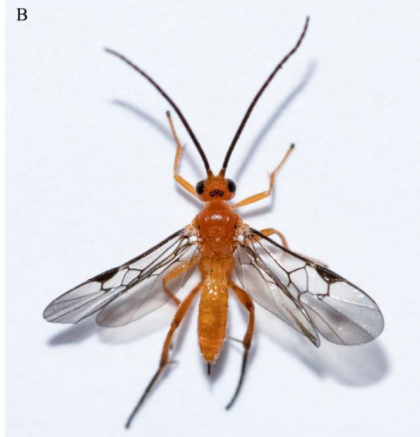

D

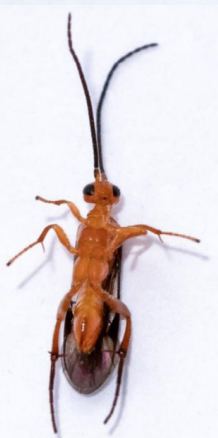

Figure 3 Female holotype of Diolcogaster choi, new species. A - dorsal shot of live female; B - dorsal habitus; C - lateral habitus; D - ventral habitus. Photos by Ísis Meri Medri.

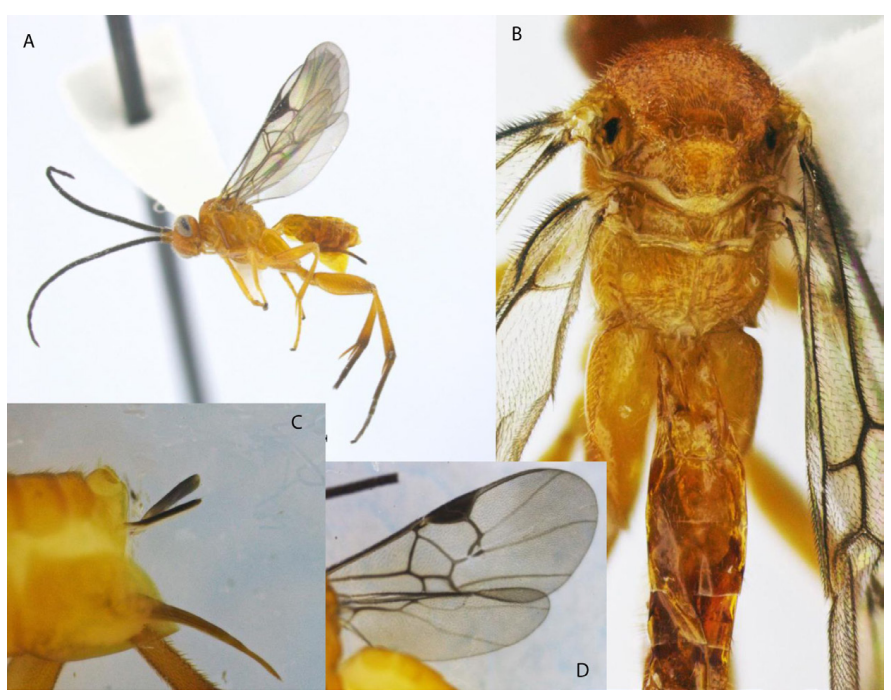

Figure 4 Diolcogaster choi, new species. A - lateral habitus of point-mounted female; $\mathrm{B}$-dorsum of mesosoma and anterior metasomal tergites; C - lateral view of tip of metasoma showing ovipositor and sheaths; D - wings venations. Photos by James Bryan Whitfield. strong and complete median carina, and additional transverse rugosity on posterior 0.6 of propodeum. Metasoma with T1 slightly widening towards posterior margin and with strong and deep median sulcus running throughout the anterior $3 / 4$ of the tergite; T2 subtriangular and posterior about same width as medial length, with relatively strong sulcus delimiting curved lateral margins; $\mathrm{T} 3+$ smooth; ovipositor sheaths weakly decurved and polished with a few scattered setae. Metacoxa relatively large, extending to end of T2. Measurements (all in $\mathrm{mm}$ ). Body length: 3.0-3.2. Fore wing length: 3.1-3.3.

Male (Fig. 5). Similar to female except medial groove of T1 reaching nearly to posterior end of tergite.

Molecular data. COI barcode deposited in GenBank (Accession MK952186).

Biology. A gregarious parasitoid, reared from Hypercompe cunigunda (Lepidoptera: Erebidae), that has potential for biological control of this caterpillar species.

Distribution. So far it has only been found in Maringá, Paraná State, Brazil; the municipality is inland, $350 \mathrm{~km}$ northwest of Curitiba city and west of the coast by $470 \mathrm{~km}$.

Etymology. The specific epithet, "choi" is in honor of the researcher Won-Young Choi, formerly of the National Institute of Biological Researches, Gyeongseo-Dong, South Korea. Choi produced a monograph on neotropical Diolcogasteras his Ph.D. dissertation at the University of Illinois, under orientation of J. B. Whitfield (Choi, 2005). Unfortunately, he tragically died in 2016 before publishing this work.

Diagnosis. Diolcogaster choisp. nov. differs, along with $D$. flammeus Salgado-Neto and Fernandez-Triana, from other described species in the Diologaster xanthaspis-group New World species in being predominantly yellow/orange in body color. From $D$. flammeus, it differs in the following combination of characters: abdominal terga almost completely orange-yellow throughout except sometimes at posterior tip of metasoma ( $D$. flammeus has much of T2-T4 darkened dorsally), percurrent medial longitudinal groove of T1 extending only 0.75 or less of distance to posterior end of tergite (in D. flammeus, essentially 0.95 or more), $\mathrm{T} 2$ posteriorly approximately as broad as medially length

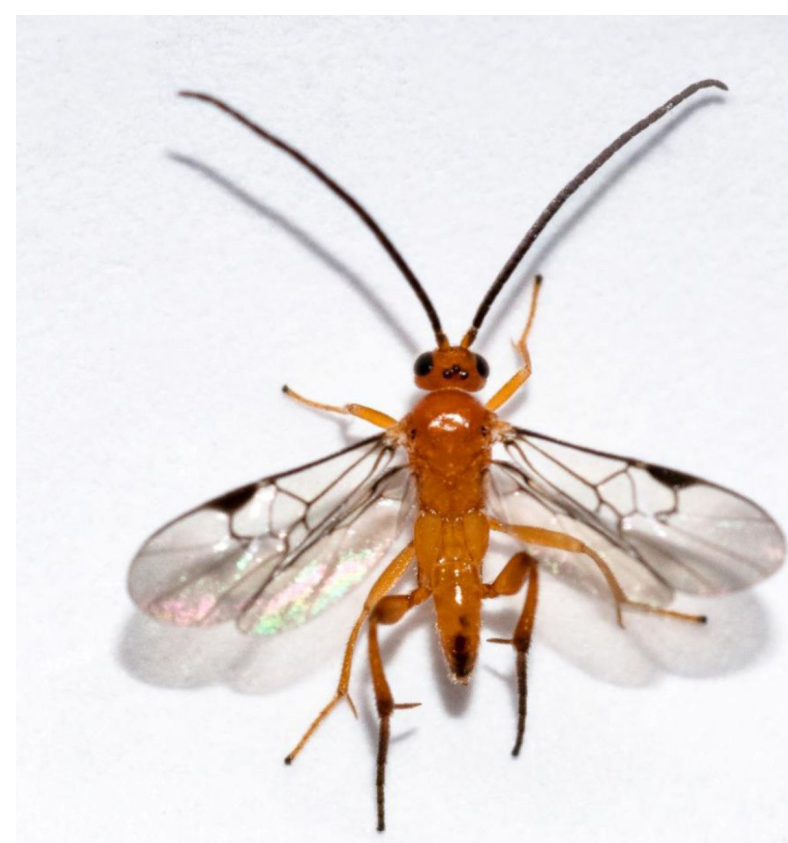

Figure 5 Male paratype of Diolcogaster choi, new species, dorsal view. Photo by Ísis Meri Medri. 
of tergite (in D. flammeus close to $1.5 \mathrm{X}$ as broad as long); ovipositor sheaths black throughout (in $D$. flammeus much paler proximally). The species also differs in recorded host, and its DNA barcode appears to be distinctive among described Diolcogaster.

Janzen does not use $2 \%$ as a cut-off for species boundaries, but instead uses extrapolation from clustering of clear within-species \% differences versus clear between-species distances. There is typically a strong difference between the magnitudes of within-species versus between-species divergences. D. choi is more or less as distinct as many other recognized species, and is definitely distinct morphologically from any of the described ones as well as very distinct in terms of barcodes from any previously described species with barcodes (top half of tree). The species status is actually based on integration of information from the morphological description, host and ecological data, and DNA barcodes, rather than simply any one of these lines of evidence.

\section{Acknowledgments}

We are grateful to: Dr. Joe Martinez (Florida Museum of Natural History) for identifying the Hypercompe species, Dr. Ricardo Harakava (Instituto Biológico) for the COI analysis and MSc. Alvaro Doria dos Santos for assistance in deposit procedures of the type specimens in the Museu de Zoologia da Universidade de São Paulo, Brazil.

\section{Conflicts of interest}

The authors declare no conflicts of interest.

\section{Author contribution statement}

Geraldo Salgado-Neto: Lead author, new species descriptor, review and organization of the main article. Ísis Meri Medri: Species collector and article writer. José L. Fernández-Triana: Assistance in the details of the description of the new species. James Bryan Whitfield: Principal descriptor of the new species, organizer of morphometric photos and finalization of the English review. Principal financier of publication costs

\section{References}

Ashmead, W. H., 1900. Report upon the Aculeate Hymenoptera of the islands of St. Vincent and Grenada, with additions to the parasitic Hymenoptera and a list of the described Hymenoptera of the West Indies. Trans. Entomol. Soc. Lond. 48 (2), 207-367. https://doi. org/10.1111/j.1365-2311.1900.tb02379.x.

Avila, G. A., Berndt, L. A., Holwell, G. I., 2013. First releases and monitoring of the biological control agent Cotesia urabae Austin and Allen (Hymenoptera: braconidae). N. Z. Entomol. 36 (2), 65-72. https:// doi.org/10.1080/00779962.2012.744908.

BoldSystems, 2019. Barcode of Life Data System. Hypercompe cunigunda. Available in: http://v4.boldsystems.org/index.php/Taxbrowser_ Taxonpage?taxid=97083 (accessed 15 April 2019).

Choi, W.Y., 2005. Systematics of the Diolcogastroid Complex (Microgastrinae: Braconidae: Hymenoptera) from the New World. Doctoral Thesis, University of Illinois, Urbana-Champaign. Available in: http://hdl. handle.net/2142/83698 (accessed 15 April 2019).

Fernández-Triana, J. L., 2015. A revision of the genus Protomicroplitis Ashmead (Hymenoptera, Braconidae, Microgastrinae), with the description of a new species. Zootaxa. 4039 (4), 529-542. https:// doi.org/10.11646/zootaxa.4039.4.3.
Fernández-Triana, J. L., 2018. Ten unique and charismatic new species of Microgastrinae wasps (Hymenoptera, Braconidae) from North America. ZooKeys. 730, 123-150. https://doi.org/10.3897/zookeys.730.22869.

Fernández-Triana, J., Boudreault, C., 2016. Keylimepie peckorum gen. n. and sp. n., (Hymenoptera, Braconidae) from southern Florida, U.S., the first known brachypterous member of the subfamily Microgastrinae. ZooKeys. 584, 95-107. https://doi.org/10.3897/ zookeys.584.8319.

Fernández-Triana, J., Boudreault, C., Buffam, J., Mclean, R., 2016. A biodiversity hotspot for Microgastrinae (Hymenoptera, Braconidae) in North America: annotated species checklist for Ottawa, Canada. ZooKeys. 633, 1-93. https://doi.org/10.3897/zookeys.633.10480.

Fernández-Triana, J., Shaw, M. R., Cardinal, S., Dosdall, L., Mason, P., 2014. First Nearctic record of Diolcogaster claritibia (Hymenoptera: Braconidae: Microgastrinae), with notes on taxonomic status and natural history. Can. Entomol. 146, 609-620. https://doi.org/10.4039/ tce.2014.16.

Fernández-Triana, J., van Atcherberg, C., 2017. Order Hymenoptera, family Braconidae Subfamily Microgastrinae from the Arabian Peninsula. In: van Harten, A. (Ed.), Arthropod Fauna of UAE. vol. 6. Departament of the President's Affair's, Abu Dhabi, pp. 275-321.

Fiaboe, K. K. M., Fernández-Triana, J., Nyamu, F. W., Agbodzavu, K. M., 2017. Cotesia icipe sp. n., a new Microgastrinae wasp (Hymenoptera, Braconidae) of importance in the biological control of Lepidopteran pests in Africa. J. Hymenopt. Res. 61, 49-64. https://doi.org/10.3897/ jhr.61.21015.

Gernaat, H. B. P. E., Hielkema, A. J., Nijman, E., Andel, T. V., 2016. Host plant and late larval stages of Hypercompe cunigunda (Erebidae: Arctiinae) in Suriname. J. Lepid. Soc. 70, 163-166. https://doi. org/10.18473/lepi.70i2.a13.

Gupta, A., Fernández-Triana, J. L., 2014. Diversity, host association, and cocoon variability of reared Indian Microgastrinae (Hymenoptera: braconidae). Zootaxa. 3800, 1-101. https://doi.org/10.11646/ zootaxa.3800.1.1.

Gupta, A., Fernández-Triana, J. L., 2015. Four new species of the genus Diolcogaster Ashmead, 1900 (Hymenoptera: Braconidae: Microgastrinae) from South East Asia with a key to the Indian species. Syst. Parasitol. 90, 285-300. https://doi.org/10.1007/ s11230-014-9546-8.

Gusmão, F. A., Harakava, R., Campos, A. E. C., 2010. Fire-Ants of the Solenopsis saevissima Species-Group (Hymenoptera: Formicidae) Nesting in Parks in the City of São Paulo: Identification Based on mtDNA Sequences and Morphological Characters. Sociobiology 56, 353-362.

Moghaddam, M. G., Mokhtari, A., 2017. The first proposal and perspective of Microgastrinae (Hymenoptera, Braconidae) in Iran as a megadiverse group: A major step in the regional studies. J. Insect Biodivers. Syst. 3, 239-246.

Moghaddam, M. G., Rakhshani, E., Achterberg, C. V., Mokhtari, A., 2019. A taxonomic review of the genus Diolcogaster Ashmead (Hymenoptera, Braconidae, Microgastrinae) in Iran, distribution and morphological variability. Zootaxa. 4590, 95-124. https://doi. org/10.11646/zootaxa.4590.1.4.

Nava, D. E., Diez-Rodríguez, G. I., Melo, M., Afonso, A. P. S., 2008. Biologia e tabela de vida de fertilidade de Hypercompe indecisa on artificial diet. Pesqui. Agropecu. Bras. 43, 1665-1669. https://doi.org/10.1590/ S0100-204X2008001200004.

Patel, S. S., 2009. Morphology and pharmacology of Passiflora edulis: A review. J. Herb. Med. Toxicol. 3, 1-6.

Patton, C. N., 1958. A Catalog of the Larvaevoridae of Florida. Fla. Entomol. 41 (2), 77-89. 
Pereira, A. G., Silva, R. B., Dias, M. M., Penteado-Dias, A. M., 2015. Study on the Hymenoptera parasitoid associated with Lepidoptera larvae in reforestation and agrosilvopastoral systems at Fazenda Canchim (Embrapa Pecuária Sudeste) São Carlos, SP, Brazil. Braz. J. Biol. 75, 783-789. https://doi.org/10.1590/1519-6984.21913.

Pinto, A. A., Teles, B. R., Penteado-Dias, A. M., 2014. First report of Phanerotoma bennetti Muesebeck (Hymenoptera, Braconidae, Cheloninae) parasitizing Hypsipyla grandella (Zeller) and Hypsipyla ferrealis Hampson (Lepidoptera, Pyralidae) in crabwood in Brazil. Braz. J. Biol. 74, 264-265. https://doi.org/10.1590/1519-6984.23812.

Pogue, M. G., 2010. The Acontiinae and Eustrotiinae (Lepidoptera: Noctuidae) of Great Smoky Mountains National Park. Zootaxa 2499, 1-20. https://doi.org/10.11646/zootaxa.2499.1.1.

Robinson, G. S., Ackery, P. R., Kitching, I. J., Beccaloni, G. W., Hernández, L. M., 2010. HOSTS - A Database of the World's Lepidopteran Hostplants. Natural History Museum, London. Available in: http:// www.nhm.ac.uk/hosts (accessed 25 April 2019).

Rodriguez, J. J., Fernández-Triana, J. L., Smith, M. A., Janzen, D. H., Hallwachs, W., Erwin, T. L., Whitfield, J. B., 2013. Extrapolations from field studies and known faunas converge on dramatically increased estimates of global microgastrine parasitoid wasp species richness (Hymenoptera: braconidae). Insect Conserv. Divers. 6 (4), 530-536. https://doi.org/10.1111/icad.12003.

Salgado-Neto, G., Fernández-Triana, J. L., Tavares, W. S., Zanuncio, J. C., 2018. Diolcogaster flammeus sp. nov. from Brazil, a new Microgastrinae wasp (Hymenoptera: Braconidae) of importance in biological control. Rev. Bras. Entomol. 62 (3), 232-236. https:// doi.org/10.1016/j.rbe.2018.06.001.

Schmitz, A., Riesner, D., 2006. Purification of nucleic acids by selective precipitation with polyethylene glycol 6000. Anal. Biochem. 354 (2), 311-313. https://doi.org/10.1016/j.ab.2006.03.014.

Silva, A. G. A., Gonçalves, C. R., Galvão, D. M., Gonçalves, A. J. L., Gomes, J., Silva, M. N., Simoni, L., 1968. Quarto Catálogo dos Insetos que Vivem nas Plantas do Brasil, Seus Parasitos e Predadores. Parte II, $1^{\circ}$ Tomo. Insetos, Hospedeiros e Inimigos Naturais. Ministério da Agricultura, Rio de Janeiro.

Singer, M. S., Bernays, E. A., 2009. Specialized generalists: behavioral and evolutionary ecology of polyphagous woolly bear caterpillars. In: Conner, W.E. (Ed.), Tiger Moths and Woolly Bears: Behavior, Ecology, and Evolution of the Arctiidae. Oxford University Press, New York, pp. 103-114.

Smith, M. A., Fernández-Triana, J. L., Eveleigh, E., Gómez, J., Guclu, C., Hallwachs, W., Hebert, P. D. N., Hrcek, J., Huber, J. T., Janzen, D., Mason, P. G., Miller, S., Quicke, D. L. J., Rodriguez, J. J., Rougerie, R., Shaw, M. R., Várkonyi, G., Ward, D. F., Whitfield, J. B., Zaldívar-Riverón, A., 2013. DNA barcoding and the taxonomy of Microgastrinae wasps
(Hymenoptera, Braconidae): impacts after 8 years and nearly 20 000 sequences. Mol. Ecol. Resour. 13 (2), 168-176. https://doi. org/10.1111/1755-0998.12038.

Spencer, K. C., Seigler, D. S., 1983. Cyanogenesis of Passiflora edulis. J. Agric. Food Chem. 31 (4), 794-796. https://doi.org/10.1021/jf00118a028.

Stojanović, D. V., Ćurčić, S. B., Orlović, S., Kereši, T., Galić, Z., 2011. The first finding of Ponometia candefacta (Hübner, 1831) (Lepidoptera, Noctuidae) in Serbia. Biljni Lek. 39, 31-36.

Tamura, K., Nei, M., 1993. Estimation of the number of nucleotide substitutions in the control region of mitochondrial DNA in humans and chimpanzees. Mol. Biol. Evol. 10 (3), 512-526. https://doi org/10.1093/oxfordjournals.molbev.a040023.

Tamura, K., Peterson, D., Peterson, N., Stecher, G., Nei, M., Kumar, S. 2011. MEGA5: molecular evolutionary genetics analysis using maximum likelihood, evolutionary distance, and maximum parsimony methods. Mol. Biol. Evol. 28 (10), 2731-2739. https:// doi.org/10.1093/molbev/msr121.

Tavares, W. S., Salgado-Neto, G., Legaspi, J. C., Ramalho, F. S., Serrão, J. E., Zanuncio, J. C., 2012. Biological and ecological consequences of Diolcogastersp. (Hymenoptera: Braconidae) parasitizing Agaraea minuta (Lepidoptera: Arctiidae) and the effects on two Costus (Costaceae) plant species in Brazil. Fla. Entomol. 95 (4), 966-970. https://doi.org/10.1653/024.095.0422.

Vincent, B., Laguerre, M., 2014. Catalogue of the Neotropical Arctiini Leach, [1815] (except Ctenuchina Kirby, 1837 and Euchromiina Butler, 1876) (Insecta, Lepidoptera, Erebidae, Arctiinae). Zoosystema 36 (2), 137-533. https://doi.org/10.5252/z2014n2a1.

Whitfield, J. B., 1997. Subfamily Microgastrinae. In: Wharton, R.A. Marsh, P.M., Sharkey, M.J. (Eds.), Manual of the New World Genera of the Family Braconidae (Hymenoptera). Special Publication of the International Society of Hymenopterists, Washington, pp. 332-364.

Whitfield, J. B., Austin, A. D., Fernández-Triana, J. L., 2018. Systematics, biology, and evolution of microgastrine parasitoid wasps. Annu. Rev. Entomol. 63, 389-406. https://doi.org/10.1146/annurevento-020117-043405.

Yeargan, K. V., Braman, S. K., 1986. Life history of the parasite Diolcogaster facetosa (Weed) (Hymenoptera: Braconidae) and its behavioral adaptation to the defensive response of a lepidopteran host. Ann. Entomol. Soc. Am. 79 (1), 1029-1033. https://doi.org/10.1093/ aesa/79.6.1029.

Yu, D. S. K., van Achterberg, C., Horstmann, K., 2016. Taxapad 2016 , Ichneumonoidea 2015. Database on Flash-Drive. Available in: http:// www.taxapad.com/ (accessed 16 April 2019).

Zeng, J., He, J. H., Chen, X. X., 2011. The genus Diolcogaster Ashmead, 1900 (Hymenoptera, Braconidae, Microgastrinae) from China. ZooKeys 129, 49-87. https://doi.org/10.3897/zookeys.129.1201. 


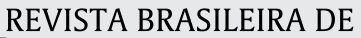

\section{Erratum}

In the article "Diolcogaster choi sp. nov. from Brazil, a new gregarious microgastrine parasitoid wasp (Hymenoptera: Braconidae) reared from Hypercompe cunigunda (Lepidoptera: Erebidae) in Brazil” with DOI number https://doi.org/10.1590/1806-9665-rbent-2019-82 published at Revista Brasileira de Entomologia v64n1:e201982 in page 5-6.

Where it was written:

Ísis Meri Medri: Species collector and English review.

Should read:

Ísis Meri Medri: Species collector and article writer. 